\title{
Avaliação das proteínas reguladoras do ciclo celular e apoptose nos Linfomas não-Hodgkin agressivos e influência na resposta ao tratamento Evaluation of cell cycle and apoptosis-regulating proteins in aggressive non-Hodgkin's lymphomas and influence in response to treatment
}

Katia B. B. Pagnano

\section{Orientadora:}

Sara Teresinha Olalla Saad

Co-orientador:

José Vassalo

\section{Resumo}

Os linfomas não-Hodgkin (LNH) agressivos constituem um grupo heterogêneo de neoplasias hematológicas. Os LNH difusos de grandes células B compreendem cerca de $20-25 \%$ dos LNH. O tratamento quimioterápico pode curar apenas $40 \%-50 \%$ dos pacientes adultos com linfomas agressivos. São considerados indicadores prognósticos: idade, número de sítios extranodais, LDH, performance status e estadiamento clínico.

Além desses fatores, anormalidades das proteínas reguladoras do ciclo celular e da apoptose parecem ser um importante mecanismo de desenvolvimento de neoplasias e podem ter um papel no prognóstico dos linfomas agressivos.

A expressão das proteínas reguladoras do ciclo celular, p53, p21/WAF-1, Mdm2 , c-Myc e PCNA (proliferating cell nuclear antigen) foram avaliadas através da análise imunohistoquímica de biópsias de gânglio, fixadas em formol e embebidas em parafina de 113 casos de LNH de alto grau de malignidade histológico, sendo que em 62 pacientes com LNH agressivos a expressão das proteínas foi correlacionada com dados clínicos e de sobrevida. Expressão de p53, p21/WAF-1, Mdm2 e c-Myc foi observada em 17/62 (30\%), 25/60 (42\%), 13/44(30\%) e 39/51 (76.5\%) dos casos, respectivamente. O fenótipo p53+/p21WAF-1 negativo, que é mais freqüentemente encontrado nos casos com mutações do $p 53$, foi associado com menor sobrevida global $(\mathrm{SG}),(P=0.04)$ e uma menor taxa de remissão completa $(\mathrm{RC})(P=0.01)$. Expressão negativa de $\mathrm{p} 53$ e c-Myc foram relacionadas a uma melhor resposta à quimioterapia ( $P=0.005$ e 0.035 , respectivamente). A expressão de p53, c-Myc e Mdm2 foi associada a uma menor SG $(P<0.001,0.05$ e 0.037 respectivamente), sugerindo que a expressão dessas proteínas poderia estar associada a um pior prognóstico nesses pacientes.

Além da análise da expressão da p53, pesquisamos a presença de mutações do gene $p 53$ nos casos com hiperexpressão da proteína $(\mathrm{n}=17)$. Foi possível extrair DNA de 15 casos. A amplificação dos éxons 5-9 do p53 teve êxito em sete casos, com o achado de uma mutação de ponto no éxon $6(\mathrm{Val} \rightarrow \mathrm{Glu} ; \mathrm{T} \rightarrow \mathrm{A})$, num paciente com hiperexpressão da $\mathrm{p} 53$ e expressão negativada p21/WAF-1

Avaliamos também a expressão de proteínas reguladoras da apoptose (p53, Bcl-2, Bax, Bak e Mcl-1) de 33 pacientes com LNH difusos de grandes células B e analisamos a relação entre a expressão dessas proteínas com dados clínicos e resposta à quimioterapia.

Nossos resultados mostraram que a expressão da p53 foi considerada um parâmetro imunohistoquímico independente relacionado a um pior prognóstico nesses linfomas. Apesar da alta expressão observada das proteínas Bcl-2, Bax, Bak e Mcl-1, não foi encontrado associação com prognóstico ou resposta ao tratamento.

Tese de Dissertação de Doutorado em Clínica Médica.

Faculdade de Ciências Médicas-Universidade Estadual de Campinas-SP-Brasil.

Correspondência para: Katia B. B. Pagnano

Departamento de Clínica Médica - Faculdade de Ciências Médicas - Unicamp - Cidade Universitária "Zeferino Vaz"

Rua Alexandre Fleming, 181 - Distrito de Barão Geraldo

13083-970 - Campinas, SP - Brazil 


\section{Summary}

Aggressive non-Hodgkin's lymphomas (NHL) form a heterogeneous group in terms of clinical presentation, histology, immunophenotype, response to treatment and prognosis. Diffuse large B-cell NHL (DLCL) constitute up to $20-25 \%$ of NHL in many series. Combination chemotherapy may cure $40-50 \%$ of adult patients. Several clinical prognostic factors have been described to predict clinical outcome, as age, $\mathrm{LDH}$, performance status and stage and are useful for identifying high-risk patients, who would benefit from a more intensive approach.

Abnormalities of cell cycle and apoptosis regulating proteins seem to be an important mechanism of tumorigenesis and may play a role in the prognosis of aggressive NHL.

The expression of p53, p21/WAF-1, Mdm2, c-Myc and proliferating cell nuclear antigen (PCNA) proteins were examined by the immunohistochemistry of paraffin embedded samples of 113 high grade non-Hodgkin's lymphomas (NHL) and in 62 patients with aggressive NHL correlated to clinical data. Expression of p53, p21/WAF-1, Mdm2 and c-Myc protein was observed in 17 out of 62 cases $(30 \%), 25$ out of $60(42 \%), 13$ out of $44(30 \%)$ and 39 out of $51(76.5 \%)$, respectively. The p $53+/ \mathrm{p} 21 \mathrm{WAF}-1$ phenotype, which is more frequently found in p53 mutations, was associated with a worse overall survival rate $(P=0.04)$ and with a lower rate of complete response $(\mathrm{CR})(P \mathrm{~F}=0.01) . \mathrm{p} 53$ and $\mathrm{c}-\mathrm{Myc}$ negative expression was related to a better response to chemotherapy $(P \mathrm{~F}=0.005$ and 0.035 , respectively). The expression of p53, c-Myc and Mdm2 was related to a shortened overall survival $(P<$ $0.001,0.05$ and 0.037 respectively), suggesting that the expression of these proteins could be associated with a poor outcomes in these patients.

We looked for mutations of $\mathrm{p} 53$ gene in aggressive NHL patients with a hyper-expression of $\mathrm{p} 53$ protein $(\mathrm{n}=17)$. DNA extraction was performed in 15 patients and PCR amplification of exons 5-9 was possible in 7 cases. We found a point mutation in exon $6(\mathrm{Val} \rightarrow \mathrm{Glu} ; \mathrm{T} \rightarrow \mathrm{A})$, in a patient with a $\mathrm{p} 53$ hyper-expression and $\mathrm{p} 21$ negative expression.

We also evaluated the expression of apoptosisregulating proteins (p53, Bcl-2, Bax, Bak and Mcl-1) of paraffin-embedded samples of 33 patients with diffuse large B-cell NHL, and assessed the relationship of these proteins to clinical outcome and response to chemotherapy.

Our results showed that p53 expression was an independent immunohistochemical parameter related to a poor prognosis in these lymphomas. Bcl-2, Bax, Bak and Mcl-1 proteins, though highly expressed in almost all cases were not associated with prognosis or response to treatment.

Avaliação: A Revista Brasileira de Hematologia e Hemoterapia publica os resumos e abstracts de teses da área apresentados em universidades que tenham programas de pós-graduação reconhecidos pelo MEC/CAPES e considere a obtenção do título suficiente para sua publicação na forma como se propõe a seção.

Recebido: $25 / 05 / 2004$

Aceito: 15/06/2004 